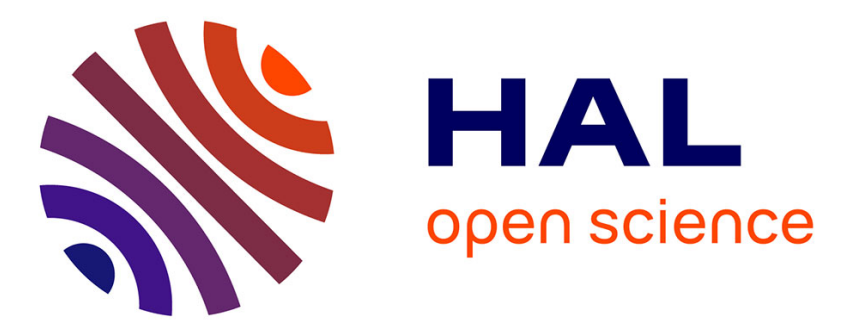

\title{
Some semen characteristics before and after freezing are repeatable and heritable in warmblood stallions
}

\author{
Anne Ricard, E. Cognard, S. Wittreck, L. Wimel, Marianne Vidament
}

\section{To cite this version:}

Anne Ricard, E. Cognard, S. Wittreck, L. Wimel, Marianne Vidament. Some semen characteristics before and after freezing are repeatable and heritable in warmblood stallions. 9. International Symposium on Equine Reproduction, International Society of Equine Reproduction (ISER). INT., Aug 2006, Kerkrade, Netherlands. 10.1016/j.anireprosci.2006.03.059 . hal-02754963

\section{HAL Id: hal-02754963 \\ https://hal.inrae.fr/hal-02754963}

Submitted on 3 Jun 2020

HAL is a multi-disciplinary open access archive for the deposit and dissemination of scientific research documents, whether they are published or not. The documents may come from teaching and research institutions in France or abroad, or from public or private research centers.
L'archive ouverte pluridisciplinaire HAL, est destinée au dépôt et à la diffusion de documents scientifiques de niveau recherche, publiés ou non, émanant des établissements d'enseignement et de recherche français ou étrangers, des laboratoires publics ou privés. 


\title{
Some semen characteristics before and after freezing are repeatable and heritable in warmblood stallions.*
}

\author{
A. Ricard ${ }^{a}$, E. Cognard ${ }^{b}$, S. Wittreck ${ }^{c}$, L. Wimel $^{d}$, M. Vidament ${ }^{c 1}$ \\ ${ }^{a}$ Génétique quantitative et appliquée, INRA, 78352 Jouy en Josas, France \\ ${ }^{b}$ Equitechnic, 61240 Le Mesnil Vicomte, France \\ ${ }^{c}$ Physiologie de la Reproduction et des Comportement, INRA, CNRS, Université de Tours, Haras Nationaux, \\ 37380 Nouzilly, France \\ ' Jumenterie, Les Haras Nationaux, Le Pin, 61310 Exmes, France
}

\section{Introduction}

The use of frozen semen is expanding in the equine industry, due to the increased acceptance of this technique by different stud-books. However, some stallions have semen that is difficult to freeze. It is then important to determine if the characteristics of this semen could be partly of genetic origin. The aim of this study was to estimate the repeatability and the heritability of some semen characteristics before and after freezing.

\section{Materials and methods}

A retrospective study was performed on freezing records (data sheets or files) of warmblood stallions whose semen was frozen at 5 French National studs between 1986 and 2002 (breeds were mainly Selle Français, but also Anglo-Arab and Arab) and at 1 private company between 1999 and 2002 (Equitechnic) (breeds were Selle Français, Anglo-Arab and Standardbred). A freezing period extended from April of one year to March of the next. Semen was frozen in INRA82 with $2 \%$ egg yolk and $2.5 \%$ glycerol with different techniques.

The four following characteristics of ejaculate were studied: gel-free volume, spermatozoa concentration, spermatozoa number in ejaculates at collection, and post-thaw motility (measured either with microscopy or with a CASA analyzer).

Non-normally distributed variables (volume, concentration and number of spermatozoa) were normalized with a Box-Cox transformation, whereas motility was normally distributed. To calculate the heritability of the semen characteristics, the model included interaction of freezing period $\mathrm{x}$ freezing technique (for motility only) $\mathrm{x}$ freezing centre, month of collection, interval between 2 collections, age of stallion, breed of stallions, permanent environmental effect for a stallion within a freezing period, permanent environmental effect for a stallion between freezing periods, genetic effect and residual. All relationships between stallions were included (source of data: SIRE, Haras Nationaux France) to estimate variance components. The software VCE (Groeneveld, 1997) was used, based on REML methodology (Restricted Estimate Maximum Likelihood).

*This paper is part of the special issue entitled Proceedings of the Ninth International

Symposium on Equine Reproduction, Guest Edited by Margaret J. Evans.

${ }^{1}$ Corresponding author. Tel: +3324742 7700 ; fax: +3324742 7743.

E-mail address: vidament@tours.inra.fr (M. Vidament). 


\section{Results}

The data included 14, 454 ejaculates from 503 stallions. These stallions were from 240 sires of whom 53 were themselves in the data. All related horses (5463) were included in the genetic analysis. The semen of these 503 stallions was frozen during a mean of 1.95 freezing periods (55\% stallions : 1 period, 20\% : 2, 25\%: 3 to 9) i.e. 982 stallions x freezing period. For motility, a mean of 29 ejaculates per stallion were analyzed (2 to 293) i.e. 15 per freezing period. For volume, spermatozoa concentration and number, only data from 9717 ejaculates were available due to lack of information in some years.

There were significant $(\mathrm{P}<0.0001)$ correlations between semen volume and spermatozoa concentration ( $\mathrm{r}=-0.57)$, between the number of spermatozoa in the ejaculate and volume ( $\mathrm{r}=0.58)$ and between the number and concentration of spermatozoa $(\mathrm{P}=0.32)$. However, correlations between these variables and post-thaw motility were extremely low (- 0.04 for the volume, 0.00 for the concentration and -0.05 for the number of spermatozoa).

For post-thaw motility results (mean $41 \% \pm 15$ (S.D.)), all the effects included in the model were significant. An improvement of more than 10 points along the years was observed which was due to two main factors: modification of the freezing technique and general, unexplained improvement with time. The other effects had an influence of less than 5 points each: positive effect of months of December/March compared to June/September (5 points), positive effect of interval between collections of 1 day compared to more than 8 days (4 points), positive effect of age until 11 years compared to 12 years and more (2 points), no effect of breed.

The repeatabilities within stallion and within freezing period and within stallion between freezing periods are reported in Table 1 . The heritabilities $\left(\mathrm{h}^{2}\right)$ of concentration, volume and number of spermatozoa were very similar $(0.17-0.18)$, the heritability of motility was slightly higher (0.27) (Table 1$)$.

Table 1. Repeatability and heritability of semen characteristics at collection (concentration, volume, number of spermatozoa) and after freezing and thawing (motility)

\begin{tabular}{lcccc}
\hline & Concentration & Volume & $\begin{array}{c}\text { Number } \\
\text { spermatozoa }\end{array}$ & $\begin{array}{c}\text { Post-thaw } \\
\text { Motility }\end{array}$ \\
\hline Genetic parameters (variance ratio) & & & & \\
$\quad$ Repeatability within freezing period & 0.57 & 0.51 & 0.47 & 0.60 \\
Repeatability between freezing periods & 0.48 & 0.41 & 0.35 & 0.51 \\
Heritability h²(= genetic part) & 0.17 & 0.18 & 0.17 & 0.27 \\
& & & & \\
Estimated standard deviation of variance ratio & & & 0.01 & 0.01 \\
Within stallion and within freezing period & 0.01 & 0.01 & 0.06 & 0.05 \\
Within stallion and between freezing periods & 0.06 & 0.05 & 0.06 & 0.05 \\
Heritability & 0.07 & 0.05 & 0.06 \\
\hline
\end{tabular}

\section{Discussion}

A nearly null relationship was found between post-thaw motility and all the other characteristics measured before freezing (volume, sperm concentration and number in the ejaculate at collection). This relationship is very poorly documented. Only Bittmar and Kosiniak (1992) have described a positive relationship between concentration and post-thaw motility on a small population of stallions whose semen was collected by keeping the first jets of ejaculate. 
The positive effect of autumn/winter months and intensive collection schedule on post-thaw motility have been described (Magistrini et al., 1987; Janett et al., 2003; Sieme et al., 2004). The weak effect of age on motility is in contradiction with data from Bittmar and Kosiniak (1992) who noted a strong positive effect of age. In our present study, the motility was a very repeatable measurement within stallion either within or between freezing periods, more repeatable than the 3 criteria before freezing. There are other reports on these four characteristics, but only within period (Pattie and Dowsett, 1982, Rousset et al., 1987).

The heritabilities of the different characteristics were found to be moderate, however these characteristics could be considered to be influenced by the genes of the stallion. By comparison, heritability of success in competition is around $0.10-0.36$ among standardbred horses and around 0.02-0.28 among jumping horses (Ricard et al (2000)) and this success is the main criterion used for selection in these populations. In the study of Tunon et al. (2000), stallions with small testes more often produce stallions with small testes and mares with low fertility, and the number of spermatozoa in the ejaculate is closely related to testis size. The genetic contribution to semen freezability has been described in roosters (Ansah et al. 1982), mice (Songsasen and Leibo, 1997) and boars (Thurston et al., 2000).

Therefore, the described characteristics could be used for future selection. Moreover, in the future, the study of the associated genes could allow an increased understanding of the biological mechanisms involved in the number of spermatozoa produced and in their resistance to freezing.

\section{References}

Ansah, G.A.' Buckland, R.B.,1982. Genetic variation in fowl semen cholesterol and phospholipid levels and the relationships of these lipids with fertility of frozen-thawed and fresh semen. Poultry Science 61, 623-637 .

Bittmar, A., Kosiniak, K., 1992. The role of selected biochemical components of equine seminal plasma in determining suitability for deep-freezing. Archivum Veterinarium Polonicum, 33,1-2.

Groeneveld, E., 1997. REML methodology. In: VCE4: User's guide and reference manual. Groeneveld publisher, FAL, Mariensee, Neustadt, Germany, p.77.

Janett, F., Thun, R., Niederer, K., Burger, D., Hässig, M., 2003. Seasonal changes in semen quality and freezability in the warmblood stallion. Theriogenology 60, 453-461.

Magistrini, M., Chanteloube, P., Palmer, E,. 1987. Influence of season and frequency of ejaculation on production of stallion semen for freezing. J. Reprod. Fert. Suppl. 35, 127-133.

Pattie, W.A., Dowsett, K.F., 1982. The repeatability of seminal characteristics of stallions. J. Reprod. Fert. Suppl. 32, 9-13.

Ricard, A., Bruns, E., Cunningham, E.P., 2000. Genetics of performance traits. In: Bowling, A.T. and Ruvinsky, A. (Eds.), The genetics of the horse. CAB International, pp 411-438.

Rousset, H., Chanteloube, P., Magistrini, M., Palmer, E., 1987. Assessment of fertility and semen evaluation of stallions. J. Reprod. Fert. Suppl. 35, 25-31.

Sieme, H., Katila, T., Klug, E., 2004. Effects of semen collection practices on sperm characteristics before and after storage and on fertility of stallions. Theriogenology 61, 769-784.

Songsasen, N., Leibo, S.P., 1997. Cryopreservation of mouse spermatozoa. II. Relationship between survival after cryopreservation and osmotic tolerance of spermatozoa from three strains of mice. Cryobiology, 35, 255269.

Thurston, L.M., Siggins, K., Mileham, A.J., Watson, P.F., Holt, W.V., 2000. Identification of amplified restriction fragment length polyporphism (AFLP) markers linked to genes controlling boar sperm viability following cryopreservation. J.Reprod. Fert. Abstract series 29.

Tunon, A.M., Emanuelson, U., Planborg, S., Malmgrem, L., 2000. Genetic transmission of reproductive traits in horses. In proceeding $14^{\text {th }}$ International Congress on Animal Reproduction, vol 1.pp.313, Abstract. 